\title{
A National-Scale Assessment of Mercury Bioaccumulation in United States National Parks Using Dragonfly Larvae As Biosentinels through a Citizen-Science Framework
}

\author{
Collin A. Eagles-Smith,* James J. Willacker, Sarah J. Nelson, Colleen M. Flanagan Pritz, \\ David P. Krabbenhoft, Celia Y. Chen, Joshua T. Ackerman, Evan H. Campbell Grant, \\ and David S. Pilliod
}

Cite This: Environ. Sci. Technol. 2020, 54, 8779-8790

Read Online

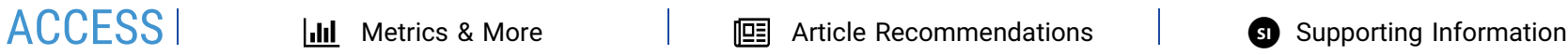
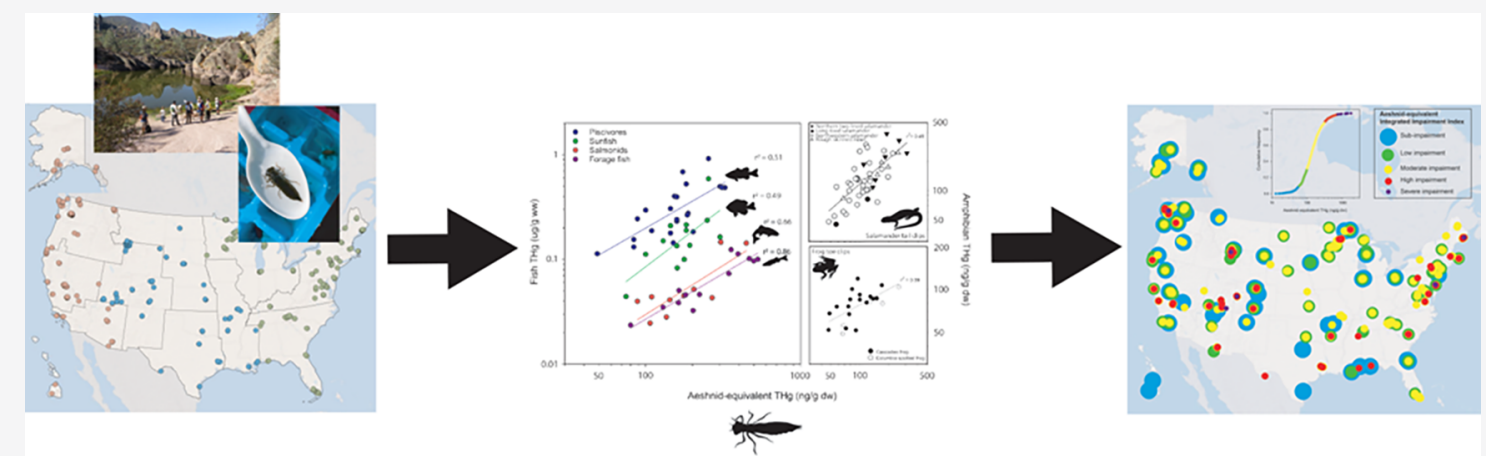

ABSTRACT: We conducted a national-scale assessment of mercury $(\mathrm{Hg})$ bioaccumulation in aquatic ecosystems, using dragonfly larvae as biosentinels, by developing a citizen-science network to facilitate biological sampling. Implementing a carefully designed sampling methodology for citizen scientists, we developed an effective framework for a landscape-level inquiry that might otherwise be resource limited. We assessed the variation in dragonfly $\mathrm{Hg}$ concentrations across $>450$ sites spanning 100 United States National Park Service units and examined intrinsic and extrinsic factors associated with the variation in Hg concentrations. Mercury concentrations ranged between 10.4 and $1411 \mathrm{ng} / \mathrm{g}$ dry weight across sites and varied among habitat types. Dragonfly total Hg $(\mathrm{THg})$ concentrations were up to 1.8 -fold higher in lotic habitats than in lentic habitats and $37 \%$ higher in waterbodies with abundant wetlands along their margins than those without wetlands. Mercury concentrations in dragonflies differed among families but were correlated $\left(\mathrm{r}^{2}>0.80\right)$ with each other, enabling adjustment to a consistent family to facilitate spatial comparisons among sampling units. Dragonfly THg concentrations were positively correlated with $\mathrm{THg}$ concentrations in both fish and amphibians from the same locations, indicating that dragonfly larvae are effective indicators of $\mathrm{Hg}$ bioavailability in aquatic food webs. We used these relationships to develop an integrated impairment index of $\mathrm{Hg}$ risk to aquatic ecosytems and found that $12 \%$ of site-years exceeded high or severe benchmarks of fish, wildlife, or human health risk. Collectively, this continental-scale study demonstrates the utility of dragonfly larvae for estimating the potential mercury risk to fish and wildlife in aquatic ecosystems and provides a framework for engaging citizen science as a component of landscape $\mathrm{Hg}$ monitoring programs.

\section{INTRODUCTION}

Environmental mercury $(\mathrm{Hg})$ contamination is recognized as a global health threat. ${ }^{1,2}$ The severity and scope of environmental and human health risks posed by $\mathrm{Hg}$ contamination have motivated landscape-level assessments of variability in mercury bioaccumulation and its drivers ${ }^{3,4}$ as well as efforts to minimize fish, wildlife, and human $\mathrm{Hg}$ exposure through reductions in environmental $\mathrm{Hg}$ releases. ${ }^{5,6}$ Biosentinels are an important tool for both landscape scale assessments and effectiveness evaluations of $\mathrm{Hg}$ reductions because inorganic $\mathrm{Hg}$ loading is often decoupled from methylmercury ( $\mathrm{MeHg}$ ) production, uptake, and biomagnification through food webs. $^{7-9}$ However, implementing a biosentinel network at broad scales can be complicated by the availability of the appropriate taxa, and the cost and logistics of executing an appropriate sampling design.

Received: February 28, 2020

Revised: June 3, 2020

Accepted: June 4, 2020

Published: July 7, 2020

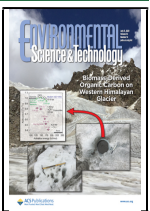


Many animals can serve as effective $\mathrm{Hg}$ biosentinels, but their utility is dependent upon both the characteristics of the organism and the inference needs of the data. ${ }^{10}$ Fish and aquatic-dependent birds are commonly used as $\mathrm{Hg}$ biosentinels because they can directly inform exposure risk to humans or other sensitive wildlife species that rely on aquatic food webs. ${ }^{11}$ However, challenges can emerge when consistent taxa are unavailable across the landscape or area of interest, ${ }^{7}$ movements obfuscate the spatial and temporal origins of bioaccumulated $\mathrm{Hg}^{12}$ or water bodies lack resident fish populations. ${ }^{13}$ Vertebrate sampling can also be impeded by logistical, regulatory, or ethical concerns. Therefore, a geographically widespread biosentinel that occurs in a variety of habitat types would be particularly valuable if it provided a reliable measure of $\mathrm{MeHg}$ bioaccumulation at fine spatial scales, informed potential wildlife exposure in both fishcontaining and fishless environments, and was logistically easy to sample.

Some aquatic insect larvae meet many of the above characteristics, but their widespread use has been limited because they can lack nexus to human exposure, may require technical expertise to identify, and exhibit low and variable percentages of methylmercury ( $\% \mathrm{MeHg}) .{ }^{14}$ Dragonfly larvae (Odonata Anisoptera) may represent an exception in many respects. Dragonfly larvae are obligate predatory invertebrates and occupy diverse freshwater habitats across six continents, ${ }^{15}$ have a narrow trophic range, and have tissues in which most $\mathrm{Hg}$ content is as MeHg. ${ }^{16-18}$ Dragonfly larvae are common even in waters where other $\mathrm{Hg}$ biosentinels, such as fish, do not occur, and their high site fidelity ensures that their tissues reflect the localized food web $\mathrm{MeHg}$ availability. ${ }^{15}$ Dragonfly larvae total mercury (THg) is well-correlated with both aqueous $\mathrm{MeHg}$ and sportfish $\mathrm{THg},{ }^{17-19}$ linking dragonflies to both environmental $\mathrm{Hg}$ concentrations and potential human exposure pathways. Moreover, dragonfly larvae can serve as vectors of aquatic-derived $\mathrm{MeHg}$ to terrestrial predators after dragonfly emergence. ${ }^{20}$ Finally, dragonfly larvae are relatively easy to collect and identify, making them ideal for nontraditional monitoring networks, such as citizen science.

Within a citizen-science framework we used dragonfly larvae as biosentinels for an assessment of $\mathrm{Hg}$ bioaccumulation in aquatic ecosystems of National Park Service units and other protected lands (hereafter NPS units). As protected environments generally free from $\mathrm{Hg}$ point sources, NPS units serve as optimal locations for evaluating the effectiveness of global $\mathrm{Hg}$ reduction efforts on $\mathrm{Hg}$ exposure in freshwater ecosystems. The goals of this effort were to (1) implement a national-scale biological $\mathrm{Hg}$ monitoring program in protected lands, (2) assess the geographic variation in dragonfly $\mathrm{THg}$ concentrations across habitat types, and (3) establish dragonflies as an effective biosentinel to inform potential exposure risk at a continental scale. We developed strict protocols and training approaches that facilitated engagement of citizen-science volunteers for sample collection in NPS units across the contiguous United States (US), Alaska, and Hawaii. We then examined the influence of intrinsic and extrinsic factors on dragonfly $\mathrm{THg}$ concentrations, and finally correlated dragonfly $\mathrm{Hg}$ concentrations with those from fishes and amphibians sampled from the same locations to determine the efficacy of dragonflies for informing $\mathrm{Hg}$ exposure and potential impairment in other taxa.

\section{METHODS}

The Dragonfly Mercury Project is a national-scale research and monitoring effort that engages citizen scientists paired with trained NPS staff to collect dragonfly larvae for $\mathrm{Hg}$ analysis at national parks across the United States (Supporting Information).

Field Sites. During 2009-2018, dragonfly larvae representing six families were collected from 457 unique locations across 100 NPS units (Figure S1). We targeted at least three sites per unit, unless there were insufficient sites in the case of small park units; the average number of sites per unit was 4.4. In total, we compiled data from 877 unique site-year combinations. Site selection was not random, but we strived to incorporate a variety of diverse habitats within each park unit to assess habitat effects of $\mathrm{Hg}$ bioaccumulation.

Sampling sites were classified as one of five primary habitats (rivers, streams, lakes, ponds, and wetlands), with these primary habitats further divided into one of 16 secondary habitats based on water permanence, proximity to hydrologically connected wetlands, and waterbody size (Table S1).

Sample Collection. Dragonfly larvae. Dragonfly larvae were sampled from each site with dip nets, generally between spring and fall. Sampling was conducted by a combination of researchers, trained NPS staff, and volunteer citizen scientists under the supervision of trained project staff, following strict sample handling and storage protocols (https://www.nps.gov/ articles/dragonfly-mercury-project.htm). Between 15 and 20 dragonfly larvae were targeted from each site and event, and efforts were made to ensure that replicates for each dragonfly family were sampled when present (Supporting Information). Each sample was double-bagged in prelabeled, polyethylene zipper-seal bags and held on wet or dry ice until transferred to a freezer within $8 \mathrm{~h}$. To minimize potential contamination, all dragonfly larvae were handled with gloved hands, or clean plastic spoons. We stored all samples at $-20{ }^{\circ} \mathrm{C}$ or colder until processing and $\mathrm{Hg}$ determination could be completed.

Fish. Fish samples were collected from a subset of the sites also sampled for dragonfly larvae. Some sites represented locations not associated with national parks but where dragonfly larvae and fish were both sampled together. From 41 unique locations, we collected several fish species representing four distinct guilds, piscivores (non-salmonid), sunfish, salmonids, and forage fish, that occur across the various habitats sampled (Table S2). Fish were collected using various methods, including electrofishing, hook and line, beach seines, and gill nets. Fish were euthanized under approved animal care and use protocols, placed into clean and labeled polyethylene bags, and stored on ice in the field until returned to the laboratory, where samples were held at $-20{ }^{\circ} \mathrm{C}$ until processing.

Amphibians. Four species of aquatic-stage salamanders and two species of adult frogs were captured at 50 and 21 sites, respectively, where dragonfly larvae were also sampled (Table S2). Amphibians were captured using dip nets or minnow traps, and then, nonlethal tissue samples (tail clips for salamanders and toe clips for frogs) were collected from each individual ${ }^{21}$ and stored frozen at $-20{ }^{\circ} \mathrm{C}$ until $\mathrm{Hg}$ determination.

Laboratory Preparation and Analysis. In the laboratory, all dragonfly, fish, and amphibian samples were dried to a constant mass and either homogenized to a fine powder or prepared for analysis whole. We determined $\mathrm{THg}$ concen- 
trations on all samples, following Environmental Protection Agency (EPA) method $7473,{ }^{22}$ and $\mathrm{MeHg}$ concentrations on a subset $(n=652)$ of samples, following EPA method $1630 .^{23}$ Methodological details and quality assurance/quality control details can be found in Supporting Information. Total $\mathrm{Hg}$ analysis was conducted at the United States Geological Survey (USGS) contaminant ecology research lab (87\% of samples; $N$ = 12845), the University of Maine ( $12 \%$ of samples; $N=$ 1842), and Dartmouth College ( $1 \%$ of samples; $N=144)$. Interlaboratory comparisons were conducted between the two primary laboratories to ensure data comparability, which are summarized in Supporting Information.

Statistical Analyses. All data were natural-log transformed prior to analyses to normalize residuals and meet the assumptions for parametric statistical tests. Unless specified otherwise, we present estimates of the central tendency as geometric or back-transformed least-squares means because of the log-normal distribution of concentration data. All statistical analyses were conducted using JMP V14.0 (SAS Institute, Cary, NC).

Intrinsic and Extrinsic Factors. We examined the importance of key intrinsic (taxonomy and body length) and extrinsic (habitat type and ecoregion ${ }^{24}$ ) variables on dragonfly $\mathrm{THg}$ concentrations using a linear mixed-effects model that included family, habitat type, and level 1 ecoregions as fixed effects and site and categorical sampling year as random effects. We also included total body length (TL) as a covariate, and TL $\times$ family, TL $\times$ site, and TL $\times$ family $\times$ site interactions. The initial model results did not support including TL in the model (see Results and Discussion); therefore, we removed TL and its associated interactions from the model. The variables selected for the model are those that have been shown to be associated with biological $\mathrm{Hg}$ concentrations at broad scales ${ }^{7}$ and represent the underlying processes and mechanisms that drive $\mathrm{Hg}$ cycling and bioaccumulation. Although sampling spanned several months, each site was generally only sampled once per year, and sites with similar climates and hydrology were usually sampled within a similar time frame. Therefore, we did not explicitly assess or account for seasonal variation in our models.

Taxonomic Conversions. We next examined relationships in $\mathrm{THg}$ concentrations among dragonfly families by correlating paired geometric mean $\mathrm{THg}$ concentrations of different families collected concurrently at the same site. For each family pair, we developed linear regression equations for predicting $\mathrm{THg}$ concentrations in one family based on those in another. The Aeshnidae family represented the largest proportion $(41 \%)$ of the data set and was consistently correlated with each of the other families. Therefore, we used the linear regression equations to convert each individual sample from the other families to an Aeshnid-equivalent $\mathrm{THg}$ concentration. By normalizing concentrations to a consistent family, the Aeshnid-equivalent concentrations allow for morerepresentative comparisons across sites and time periods without confounding effects of taxonomy.

Bioindicator Suitability. The suitability of dragonfly larvae as biosentinels of $\mathrm{THg}$ exposure in aquatic ecosystems is partly predicated on their ability to provide inference about $\mathrm{THg}$ exposure in other aquatic organisms at multiple levels of the food web. To examine this, we paired collections of dragonflies at a subset of sites where either fish or amphibian species were also sampled. At each of these sites, we generated an Aeshnidequivalent site-year geometric mean $\mathrm{THg}$ concentration to ensure representative units were used for dragonfly $\mathrm{Hg}$ concentrations.

We similarly calculated site-year geometric mean $\mathrm{THg}$ concentrations for each fish guild and both salamanders and frogs. However, limited sample sizes and a diverse range of species precluded adjusting concentrations to a single taxon for each group, as was done with the dragonfly larvae. We chose a guild-based approach because it aggregated related fish species with a similar trophic ecology into discrete categories that are applicable across a wide geographic range and multiple habitat types. After calculating site- and taxa-specific geometric mean $\mathrm{THg}$ concentrations for the fish and amphibians, we used linear regression models for each taxonomic group to quantify the relationship in $\mathrm{THg}$ concentrations between dragonfly larvae and other aquatic taxa.

\section{RESULTS AND DISCUSSION}

From 2009 to 2018, more than 4000 citizen scientists contributed to the collection of 14831 dragonfly larvae from 457 individual sites in 100 different NPS units across the US, including Alaska and Hawaii (Figure 1). The geometric mean ( \pm geometric standard error) $\mathrm{THg}$ concentration $[\mathrm{ng} / \mathrm{g}$ dry weight $(\mathrm{dw})]$ of all individual dragonfly larvae was $125 \pm 2.2$ (arithmetic mean \pm standard deviation $=181 \pm 217)$. The park units (park unit type abbreviations are defined in Table S3) with the highest geometric mean $\mathrm{THg}$ concentrations across all sites included Colorado NM, Bear Meadows NNL, Minute Man NHP, and Maurice WSR, whereas those with the lowest concentrations included Bear Creek Lake Park, Padre Island NS, Fort Worth NNL, and Buffalo NR (Figure 1). Individual sites with the highest $\mathrm{THg}$ concentrations were in Olympic NP $(1411 \pm 41)$, Acadia NP (1319 \pm 319$)$, Glen Canyon NRA ( $1207 \pm 86)$, Maurice WSR (905 \pm 38 ; $854 \pm$ $32 ; 745 \pm 36)$, Capitol Reef NP $(672 \pm 92)$, and Yellowstone $\mathrm{NP}(626 \pm 20)$, whereas those with the lowest $\mathrm{THg}$ concentrations were found in Bear Creek Lake Park (10.4 \pm 1.2), Gulf Island NS (16.4 \pm 1.6$)$, Padre Island NS (17.6 \pm 5.2), Buffalo NR $(20.6 \pm 2.5)$, and Forth Worth NNL (21.7 \pm $1.8)$.

In a subset of individuals $(N=652)$ analyzed for both $\mathrm{MeHg}$ and $\mathrm{THg}, \mathrm{MeHg}$ concentrations ranged from 12.3 to $1870 \mathrm{ng} / \mathrm{g} \mathrm{dw}$ and were strongly correlated with $\mathrm{THg}$ concentrations $\left(R^{2}=0.96, p<0.0001\right.$; Figure S2). Additionally, the \% $\mathrm{MeHg}$ (proportion of $\mathrm{THg}$ in the $\mathrm{MeHg}$ form) averaged $( \pm \mathrm{SE}) 79.9 \pm 0.5 \%$ of $\mathrm{THg}$ concentrations, which is similar to the ranges $(83-94 \%)$ reported elsewhere. ${ }^{16,18}$ Collectively, these findings suggest that, unlike other aquatic macroinvertebrate species where low and variable $\% \mathrm{MeHg}$ is a major limitation to their use as $\mathrm{Hg}$ bioindicators, $\mathrm{THg}$ serves as an effective proxy for $\mathrm{MeHg}$ concentrations in dragonfly larvae. Therefore, we use $\mathrm{THg}$ concentrations for further data analysis.

Variation within and among Parks. Individual dragonfly larvae $\mathrm{THg}$ concentrations spanned four orders of magnitude, from 1.0 to $3795 \mathrm{ng} / \mathrm{g} \mathrm{dw}$ across all sites. Consistent with such a broad range in concentrations, the data set's geometric coefficient of variation (GCV) was $96 \%$, indicating a high degree of variability across the landscape. However, the average GCV $( \pm \mathrm{SE})$ within sites (with $n \geq 10$ ) was nearly 3-fold less $(35.3 \pm 0.95 \%)$, and within-site GCVs were not correlated with their paired site-specific geometric mean $\mathrm{THg}$ concentrations $(p=0.84, n=412)$, indicating that the within-site variation in $\mathrm{THg}$ concentrations was relatively similar 


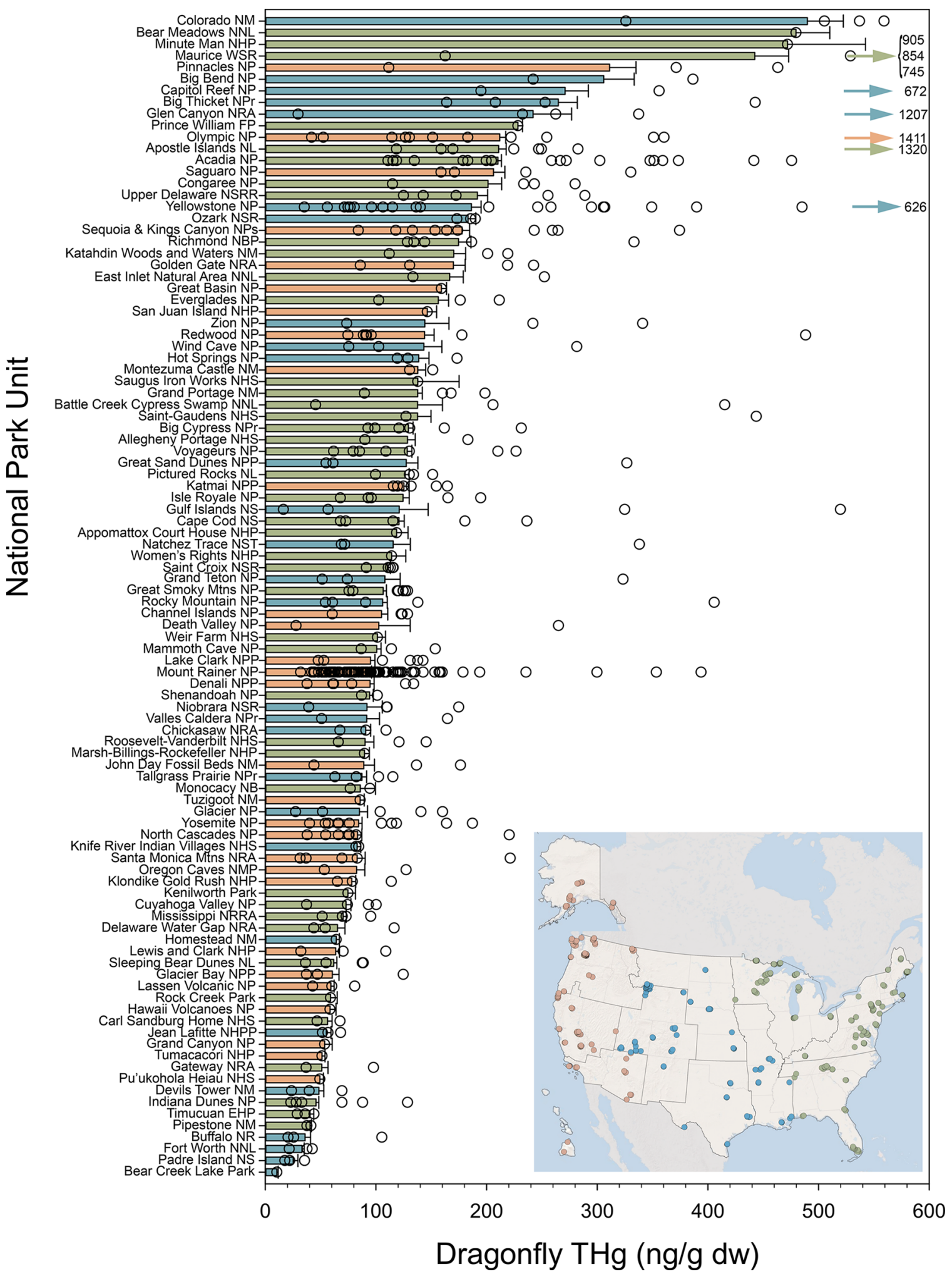

Figure 1. Total mercury (THg) concentrations (ng/g dry weight) in dragonfly larvae collected from National Park units across the conterminous US, Alaska, and Hawaii. Bars represent park unit geometric means $( \pm \mathrm{SE})$, and circles represent geometric mean THg concentrations for individual sampling sites (populations) within each unit. Colors represent aggregations of US Department of Interior regions representative of western (orange), central (blue), and eastern (green) areas, as illustrated in the inset map. Arrows and associated text represent sites with geometric mean THg concentrations beyond the extent of the $x$-axis. Unit name suffixes are provided in Table S3. Note that the map geography is not to scale. Alterations were made to include Alaska and Hawaii within the map frame. Bear Creek Lake Park is not a NPS administered unit.

regardless of the overall $\mathrm{Hg}$ condition of a site. These findings suggest that the variation in $\mathrm{THg}$ concentrations among sites at a continental scale is substantially higher than within sites.
Indeed, site-specific geometric mean $\mathrm{THg}$ concentrations ranged 135-fold (10.4-1411 ng/g dw; Figure 1), and the GCV among all sites (86\%) was more than double the average 
GCV within sites, where concentrations ranged 5.7-fold, on average (range $=1.2-100$-fold). Importantly, even within individual national park units, which is a substantially finer scale than across the US, and where sites are in relatively close proximity to one another, the average $( \pm S E)$ for among-site GCV $(62.7 \pm 6.5 \%)$ was similar to the GCV among national parks $(68.7 \%)$. This highlights the importance of site-specific characteristics on $\mathrm{Hg}$ bioaccumulation.

Site is often a dominant factor in influencing $\mathrm{Hg}$ bioaccumulation, ${ }^{7,25,26}$ resulting in substantial geographic variation. Mean fish $\mathrm{THg}$ concentrations in 206 species varied 496-fold across >4000 locations throughout western North America, ${ }^{7}$ and species-normalized concentrations varied 96fold in nearly 2000 sites across Canada, ${ }^{27}$ similar to the range of variation we found (135-fold) in dragonfly larvae. This variation is not constrained to continental-scale assessments nor likely due to the direct inorganic $\mathrm{Hg}$ contamination. For example, fish $\mathrm{THg}$ concentrations in 28 high-elevation lakes of eastern Oregon, US varied 18 -fold, ${ }^{28}$ despite being free from direct watershed disturbance and receiving a similar atmospheric $\mathrm{Hg}$ deposition. Furthermore, $\mathrm{THg}$ in fish from national parks in the western US varied between 10- and 24-fold among sites. $^{29,30}$ Even at more local scales, fish $\mathrm{Hg}$ concentrations of individual wetlands in the San Francisco Bay region of California varied by 15 -fold despite only being separated by narrow levees. ${ }^{31}$ Likewise, we found high variation within individual national parks, where dragonfly larvae $\mathrm{THg}$ concentrations varied 33-fold across 13 sites in Olympic NP, 32-fold between two sites in Gulf Islands NS, 13-fold in 85 sites from Mount Rainier NP, 12-fold among 20 sites in Acadia $\mathrm{NP}$, and 11-fold across 17 sites in Yellowstone NP.

Because inorganic $\mathrm{Hg}$ contamination is generally decoupled from $\mathrm{MeHg}$ production, uptake, and bioaccumulation, ${ }^{4}$ the high variability among sites (both within and among national parks) is likely a result of site-specific biogeochemical and ecological factors that control net $\mathrm{MeHg}$ production and bioavailability within ecosystems. In fact, the variation in dragonfly $\mathrm{THg}$ concentrations (135-fold across sites) was an order of magnitude higher than the variation in $\mathrm{THg}$ wet deposition across the US ( $\sim 10$-fold across sites; http://nadp. slh.wisc.edu/). Thus, we next examined key extrinsic factors known to influence biological $\mathrm{MeHg}$ exposure along with intrinsic factors that influence individual-level bioaccumulation.

In our initial global model, the length $\times$ family $(p<0.0001)$ and length $\times$ site $(p<0.0001)$ interactions indicated potential site- or family-dependent relationships between length and $\mathrm{THg}$ concentrations. Therefore, we conducted individual regressions for each family and sampling site where there were at least 15 samples from a given year (site-years across five families; Table S4). Length and THg concentrations were significantly correlated $(p<0.05)$ in only 82 (out of $298 ; 28 \%$ ) site-years (Aeshnidae $=34 \%$, Cordulegastridae $=7 \%$, Gomphidae $=17 \%$, and Libellulidae/Corduliidae $=26 \%$ ). However, of the 82 site-years with a significant correlation between $\mathrm{THg}$ concentration and dragonfly length, 54 (66\%) were positive correlations, and the remaining 28 (34\%) were negative. Moreover, the average $R^{2}$ value for all significant regressions (positive or negative) was only 0.37 , and only $22 \%$ of site-years had $R^{2}$ values $>0.50$, indicating that the body length was neither an overwhelming nor consistent variable associated with dragonfly $\mathrm{THg}$ concentrations. Because of the limited explanatory power and substantial variation in the directional effect of body length on $\mathrm{THg}$ concentrations, we did not size-adjust dragonfly $\mathrm{THg}$ concentrations, and we removed the length from subsequent models.

Extrinsic Drivers: Habitat and Ecoregion. In the reduced model (i.e., excluding length), dragonfly $\mathrm{THg}$ concentrations differed among primary habitats $\left(F_{4,438.3}=7.30 ; p<0.0001\right)$, secondary habitats $\left(F_{1,1488.4}=3.54 ; p<0.0001\right)$, and among ecoregions $\left(F_{1,2435.4}=4.99, p<0.0001\right)$. Among the five primary habitat types, dragonfly larvae $\mathrm{THg}$ concentrations were highest in rivers and streams (Figure 2). Post hoc pairwise

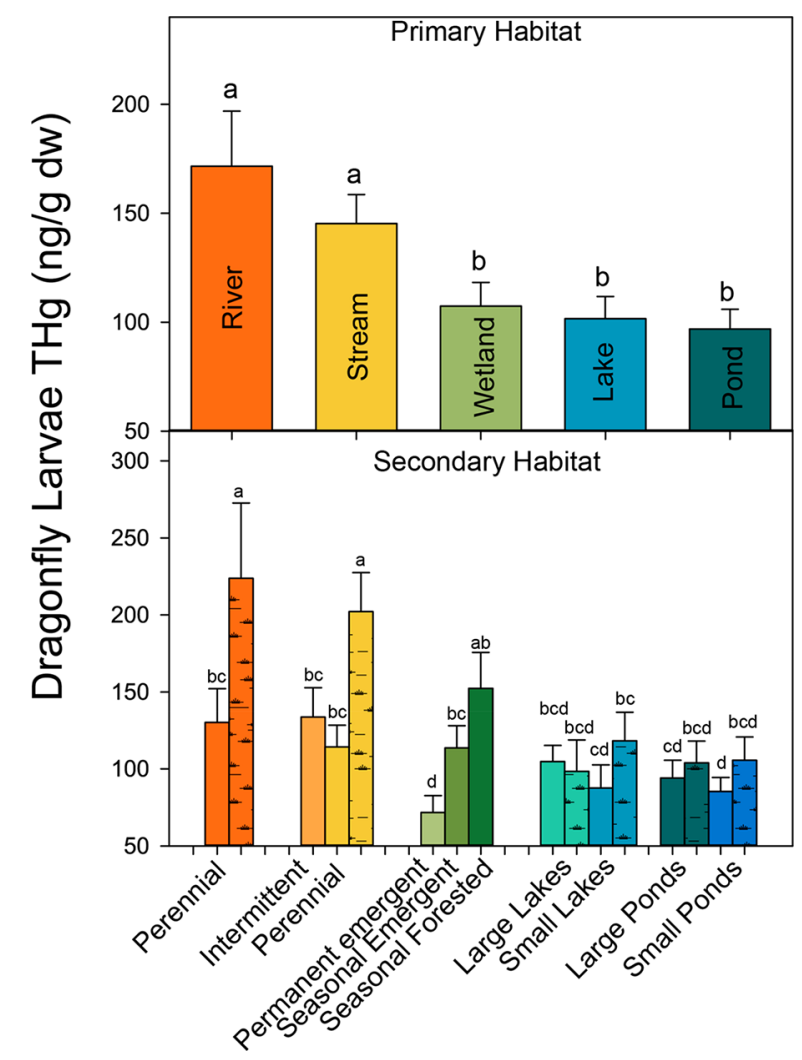

Figure 2. Least squares mean $\mathrm{THg}$ concentrations (ng/g dry weight) in dragonfly larvae among habitat types in national park units across the US. Least squares mean $\mathrm{THg}$ concentrations account for the effects of family, ecoregion, site, and year. Patterned bars in secondary habitats represent those bounded by extensive marginal wetlands. Letters represent the significance at $\alpha=0.05$ based on pairwise contrasts and test slices.

contrasts indicated that riverine dragonflies had higher concentrations than those in all other habitat types except streams (streams, $F_{1,432}=1.17, p=0.28$; lakes, $F_{1,429.8}=11.3, p$ $=0.0009$; wetlands, $F_{1,432.1}=9.03, p=0.003$; ponds, $F_{1,435.2}=$ 15.1, $p<0.0001)$; stream dragonflies also were higher than those from the other three habitats (wetlands, $F_{1,431.9}=8.35, p$ $=0.004$; ponds, $F_{1,439.2=18.0}, p<0.0001$; lakes, $F_{1,429}=9.75, p=$ 0.002 ), which did not differ from one another.

Among nested secondary habitats (Figure 2), $\mathrm{THg}$ concentrations differed within rivers $\left(F_{2,436.1}=84.1, p<\right.$ $0.0001)$, wetlands $\left(F_{2,427.7}=7.74, p=0.0005\right)$, and streams $\left(F_{2.430 .8}=7.69, p=0.0005\right)$ but not lakes $\left(F_{2,424.6}=0.29, p=\right.$ $0.74)$ nor ponds $\left(F_{2,857.2}=1.42, p=0.24\right)$. In rivers and streams, $\mathrm{THg}$ concentrations were $71 \%$ and $76 \%$ higher, respectively, in sites with adjacent riparian wetlands and floodplains (rivers, $F_{1,431.8}=4.43, p=0.03$; streams, $F_{1,431.4}=$ $14.9, p<0.0001)$. However, perennial and intermittent streams 


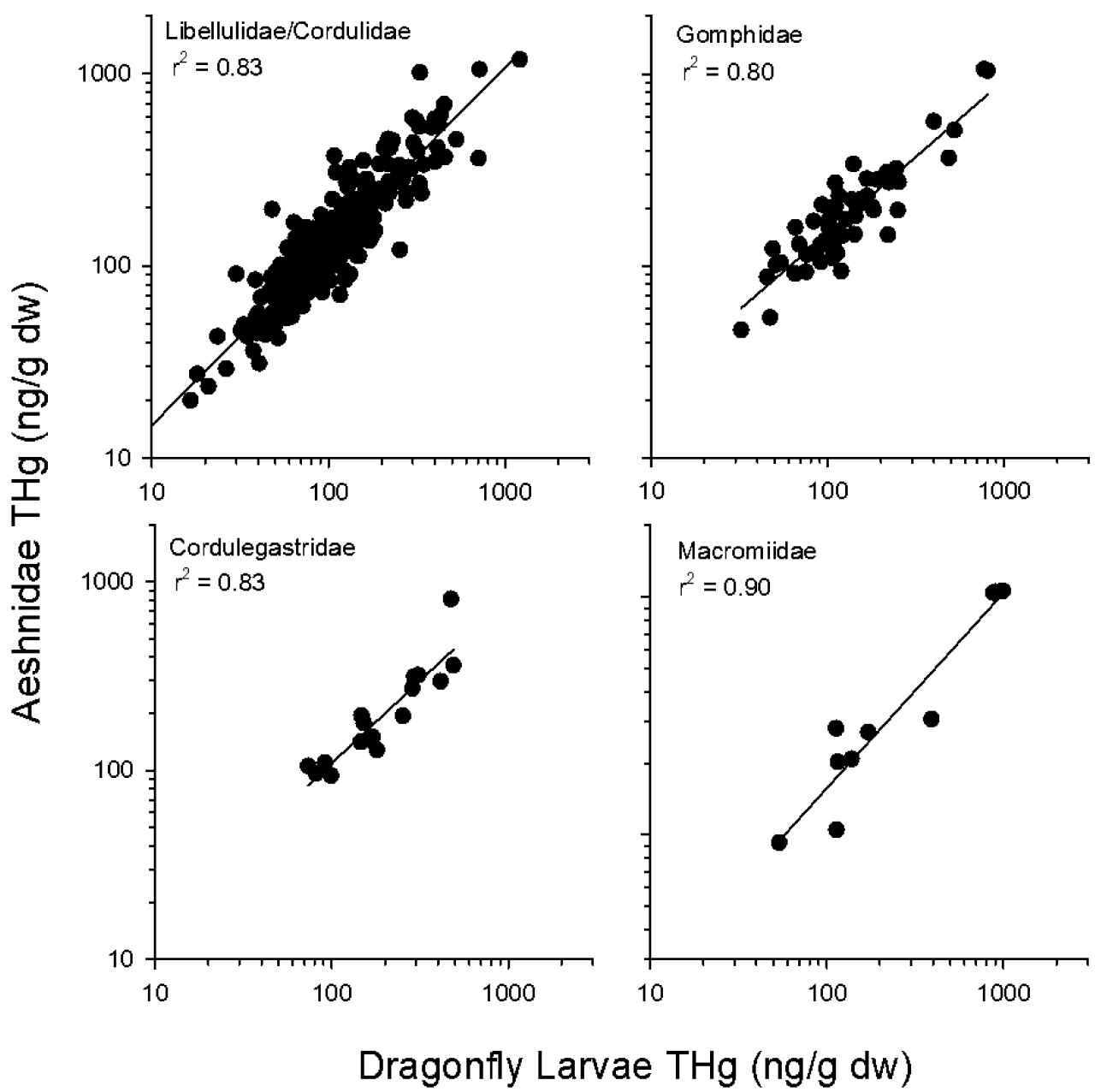

Figure 3. Relationships of total mercury $(\mathrm{THg})$ concentrations in dragonfly larvae among families. Each data point represents a paired site-year geometric mean $\mathrm{THg}$ concentration for each family. The $x$-axis represents geometric mean concentrations for the family listed in each pane; $y$-axis represents paired THg concentrations in the Aeshnidae family. Libellulidae and Corduliidae are combined as a single family group because their distinction can be uncertain without the identification of the genus.

without marginal wetlands did not differ from one another $\left(F_{1,430.5}=0.85, p=0.36\right)$, suggesting that the proximity to wetlands may have a stronger influence on $\mathrm{MeHg}$ bioaccumulation in streams than water permanence. In contrast, within wetlands themselves, seasonally inundated emergent and forested wetlands had $58 \%$ and $112 \%$ higher $\mathrm{THg}$ concentrations, respectively, than permanently inundated wetlands (emergent, $F_{1,427.9}=6.81, p=0.009$; forested, $F_{1,425.5}=6.81, p$ $<0.0001)$. Across all of the secondary habitats, dragonflies from perennial rivers with marginal wetlands (the habitat with the highest concentrations) were 3.1-fold higher than those from the lowest habitat (permanent emergent wetlands). Although differences were not consistently significant in all habitat types, those bounded by marginal wetlands averaged $\mathrm{THg}$ concentrations that were $35 \%$ higher than similar habitats without wetlands.

These habitat differences further highlight the importance of ecological factors as key drivers of spatial variability in biological $\mathrm{Hg}$ concentrations. $\mathrm{Hg}$ exposure being the highest in lotic and lowest in lentic habitats is consistent with other independent data sets, where fish $\mathrm{THg}$ concentrations were $21 \%-61 \%$ higher in lotic than lentic waterbodies across western North America ${ }^{7}$ and northeastern US lakes. ${ }^{32}$ An important caveat to this is that dragonfly larvae $\mathrm{THg}$ concentrations from lakes (particularly large lakes) primarily represent a littoral zone analysis and likely do not effectively integrate pelagic pathways of $\mathrm{Hg}$ bioaccumulation. Importantly, water bodies bounded by extensive wetlands and floodplains generally had the highest dragonfly $\mathrm{THg}$ concentrations, despite lower concentrations in dragonflies sampled from wetlands themselves (except seasonal forested wetlands) than in either rivers or streams. Wetlands are known sites of $\mathrm{MeHg}$ production, ${ }^{33}$ and wetland density can be a strong predictor of aqueous $\mathrm{MeHg}$ concentrations of streams. ${ }^{34,35}$ The apparent discrepancy between these habitats may be a function of dissolved organic carbon (DOC) dynamics. Elevated DOC is common in wetlands, and DOC can both promote $\mathrm{MeHg}$ production and transport but also inhibit $\mathrm{MeHg}$ bioaccumulation. ${ }^{36-38}$ Thus, high DOC in wetlands can result in lower $\mathrm{MeHg}$ bioaccumulation factors within wetlands themselves by binding $\mathrm{MeHg}$ and making it less bioavailable. ${ }^{39}$ At the same time, DOC can facilitate $\mathrm{THg}$ and $\mathrm{MeHg}$ transport to surrounding rivers and streams where it may become more bioavailable in a lower DOC environment. Indeed, dragonfly $\mathrm{THg}$ concentrations were positively correlated with lake DOC concentrations across a series of lakes in the northeastern US, but the DOC inhibition effect 


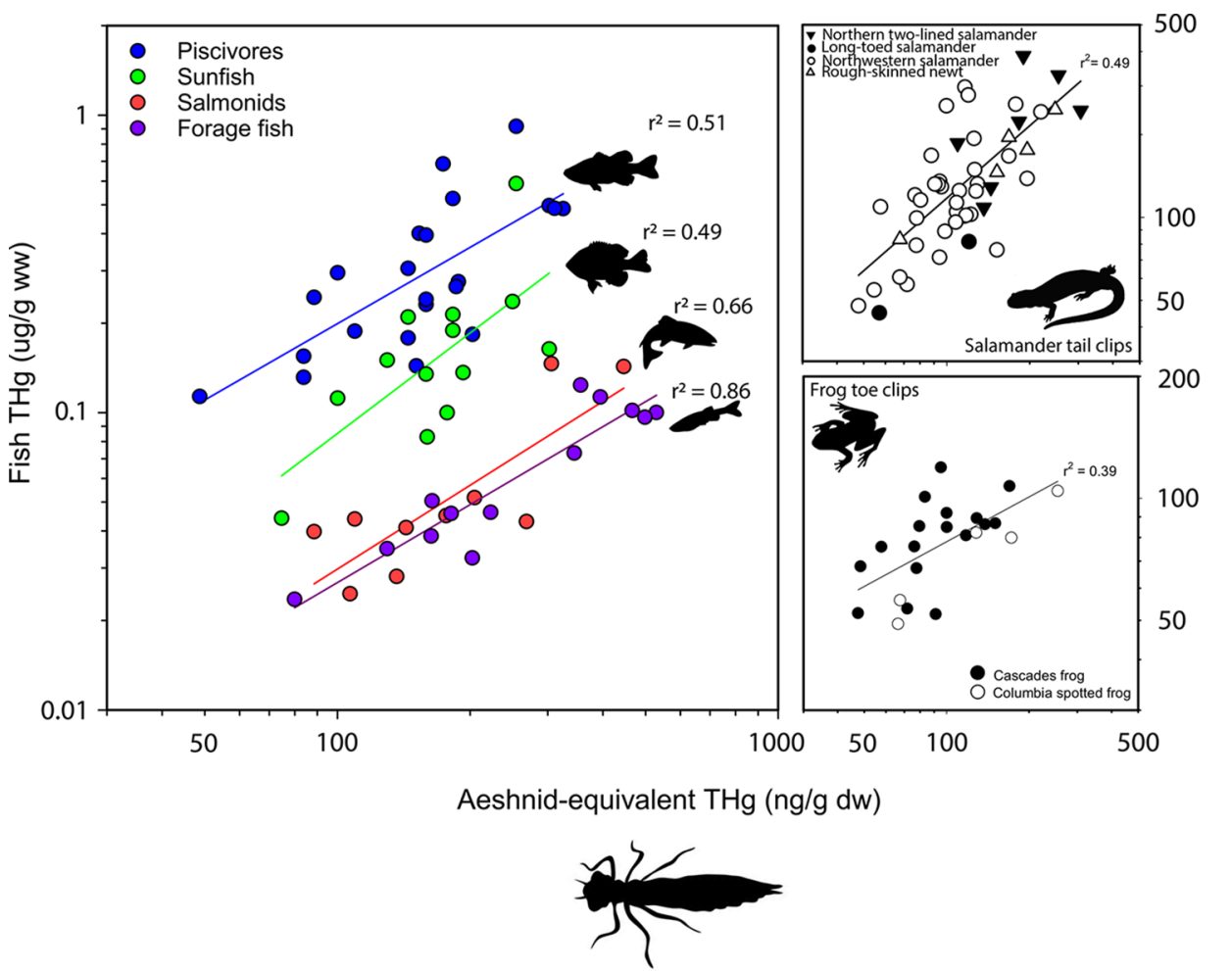

Figure 4. Relationship between Aeshnid-equivalent dragonfly larvae THg concentrations (ng/g dw) and THg concentrations ( $\mu \mathrm{g} / \mathrm{g}$ wet weight $(\mathrm{ww})$ ) in four fish guilds (left panel), salamander tail clips (ng/g dw; top right panel), and frog toe clips (ng/g dw; bottom right panel. Each data point represents the paired geometric mean $\mathrm{THg}$ concentrations for sites where both dragonfly larvae and either fish or amphibians were sampled. Fish THg concentrations are reported in wet weight to facilitate comparisons to common health benchmarks, whereas dragonfly larvae and amphibian concentrations are reported on a dry weight basis to reduce variance associated with external moisture.

was observed in bioaccumulation factors for dragonfly $\mathrm{THg}$ across the range of measured DOC. ${ }^{18}$

At a broader spatial scale, the influence of the habitat type and ecological factors on $\mathrm{Hg}$ bioaccumulation is illustrated by differences among level 1 ecoregions, which represent broad areas of similar geography, geology, climate, and basic biological organization, which in turn influence the structure and function of specific ecosystems. ${ }^{40}$ After statistically accounting for taxonomy, habitat, and site, we found substantial variation in $\mathrm{THg}$ concentrations among these ecoregions (Figure S3), with a 3.6-fold range in $\mathrm{THg}$ concentrations between the lowest (Great Plains) and the highest (North American Deserts) ecoregions. Arid ecoregions such as North American Deserts and Southern Semiarid Highlands were particularly elevated in $\mathrm{THg}$ concentrations, both in the studied dragonflies and in previously reported fishes across western North America, ${ }^{7}$ whereas $\mathrm{THg}$ concentrations in Taiga were similarly low in both dragonflies and fish. Hydrology can be an important driver of $\mathrm{MeHg}$ production and bioaccumulation, ${ }^{41}$ and arid ecoregions represent areas where many waterbodies are only seasonally inundated and anthropogenic water impoundments (i.e., reservoirs) are widespread. Drying and rewetting of littoral sediments inherent to reservoirs can exacerbate $\mathrm{Hg}$ methylation and increase $\mathrm{MeHg}$ bioaccumulation in food webs both within and downstream of impoundments, ${ }^{42-44}$ which may influence dragonfly $\mathrm{THg}$ concentrations in these arid areas. Similarly, we found that dragonflies from seasonal wetlands had substantially higher $\mathrm{THg}$ concentrations than those from permanently inundated wetlands, findings consistent with those of others from managed wetland systems where cyclic wetting and drying patterns allowed for the reoxidation of terminal electron acceptors that are important for $\mathrm{MeHg}$ production. ${ }^{9,45,46}$

Intrinsic Drivers: Taxonomy and Body Size. Taxonomy can influence $\mathrm{Hg}$ concentrations across phylogenetic categories because it incorporates differences in foraging ecology, habitat use, and bioenergetics. Consistent with this, we found that $\mathrm{THg}$ concentrations $(\mathrm{ng} / \mathrm{g} \mathrm{dw})$ differed among larval dragonfly families $\left(F_{4,14585}=251.0, p<0.0001\right.$; Figure S4). Aeshnidae $(141 \pm 11.0)$ had the highest $\mathrm{THg}$ concentrations, followed by both Macromiidae $(131 \pm 10.9)$ and Cordulegastridae $(131 \pm$ 10.7), which did not differ from one another. Libellulidae and Corduliidae $(116 \pm 9.0)$, which were categorized together because of the uncertainties in their differentiation at this resolution, were significantly lower than the preceding three families but higher than Gomphidae $(95.0 \pm 7.5)$, which had the lowest $\mathrm{THg}$ concentrations, and were 1.5 times lower on average than Aeshnids (Figure S4).

The mechanisms for taxonomic differences require more study but are likely tied to some combination of foraging ecology, habitat use, and physiology. ${ }^{47}$ Dragonfly larvae are commonly described in terms of one of four categories: claspers (Aeshnidae), sprawlers (Macromiidae, Corduliidae, Libellulidae), hiders (Cordulegastridae), and burrowers (Gomphidae), which represent their preferred microhabitats and activity levels. ${ }^{15}$ Although some species in each family fall into different categories, these generalized microhabitat distinctions likely influence both diet and energetics. We limited our identification to the family level, which may add unexplained variation if species-specific differences in $\mathrm{THg}$ bioaccumulation are pronounced within families. This requires 
further investigation, but there was low variation among Gomphidae species across 17 lakes in the Laurentian Great Lakes region. ${ }^{17}$

Resilience to the confounding effects of intrinsic factors that influence $\mathrm{Hg}$ concentrations is among the most important aspects of effective $\mathrm{Hg}$ biosentinels. Of the two common intrinsic factors that we examined (body size ${ }^{48}$ and taxonomy ${ }^{7}$ ), which integrate other important factors such as foraging ecology and physiology, only taxonomy consistently influenced $\mathrm{THg}$ concentrations. However, paired geometric mean $\mathrm{THg}$ concentrations of dragonfly larvae sampled from the same location at the same time were strongly correlated among all family pairs (Figure 3; equations $S 1-S 5$ ), except Macromiidae and Cordulegastridae, a pair we could not test because they were concurrently sampled at only five sites. These relationships between families at a national scale facilitate a simple approach to reliably convert $\mathrm{THg}$ concentrations from one family to those of another family, making it possible for equivalent comparisons among locations or over time where the same families were not sampled. Similar approaches have been used for both wildlife and fish ${ }^{27,49}$ to ensure robust comparisons among locations or to estimate the likely wildlife $\mathrm{Hg}$ exposure on the basis of their prey. ${ }^{50,51}$ To facilitate the use of dragonfly $\mathrm{THg}$ data across landscapes where the same families may not be sampled, we provide regressions for each family pair in Supporting Information.

Relationships with Fish and Wildlife Hg Exposure. Aeshnid-equivalent $\mathrm{THg}$ concentrations were positively correlated with $\mathrm{THg}$ concentrations in all four fish guilds (Figure 4): piscivores $\left(F_{1,21}=20.9 ; p=0.0002, N=22\right.$ sites), sunfish $\left(F_{1,12}=10.4 ; p=0.008, N=13\right.$ sites $)$, salmonids $\left(F_{1,9}=\right.$ $15.5 ; p=0.004, N=10$ sites $)$, and forage fish $\left(F_{1,12}=65.1 ; p<\right.$ $0.0001, N=13$ sites), as well as with those in both salamanders $\left(F_{1,50}=45.1 ; p<0.0001, N=51\right.$ sites $)$ and frogs $\left(F_{1,21}=12.6\right.$; $p=0.002, N=22$ sites) (Figure 4).

The ability to predict $\mathrm{THg}$ concentrations in other components of aquatic food webs is a particularly important aspect of dragonflies as $\mathrm{Hg}$ biosentinels. These relationships, spanning classes of organisms as well as guilds within them, at a national scale, suggests transferability to broad scales and across ecosystems. These findings provide the underpinnings of a tool for estimating the potential risk due to $\mathrm{Hg}$ exposure across multiple taxa. Haro et al. ${ }^{17}$ similarly showed strong relationships between site-specific $\mathrm{THg}$ concentrations in Gomphidae and those in both forage fish and predatory fish. However, they estimated that Gomphidae THg concentrations of $40 \mathrm{ng} / \mathrm{g}$ of $\mathrm{dw}$ were associated with muscle $\mathrm{THg}$ concentrations in predatory fishes equivalent to the US EPA $\mathrm{MeHg}$ criterion value for the protection of human health (0.30 $\mu \mathrm{g} / \mathrm{g}$ of wet weight $(\mathrm{ww}))$. Our findings for piscivorous fishes were substantially more conservative, suggesting that the EPA criterion was reached when Aeshnid-equivalent $\mathrm{THg}$ concentrations exceeded $162 \mathrm{ng} / \mathrm{g}$ of $\mathrm{dw}$, which corresponds to approximately $112 \mathrm{ng} / \mathrm{g}$ in Gomphidae. The reason for this discrepancy is unclear but could be associated with differences in the geographic scale of these studies (i.e., models derived from similar habitats and a narrower geographic region (Great Lakes region) as opposed to those from a more diverse assortment of habitats at a continental scale). Alternatively, it could simply be the result of different statistical approaches used to generate site-specific mean $\mathrm{THg}$ concentrations (geometric means vs arithmetic means). Regardless, the similar strength and slopes of the relationships between the two studies highlight the utility of using dragonflies as an index of fish $\mathrm{Hg}$ exposure across a variety of scales.

Integrated Impairment Index. Dietary- and tissue-based impairment benchmarks provide estimates of the potential toxicological risk of $\mathrm{Hg}$ to fish and wildlife ${ }^{52-55}$ as well as to humans through fish consumption. ${ }^{56}$ For each fish guild, we used the linear regressions described above to model the Aeshnid-equivalent $\mathrm{THg}$ concentrations that would be indicative of levels exceeding published health benchmarks that span a range of potential hazard (Table S5). We also modeled the Aeshnid-equivalent $\mathrm{THg}$ concentrations that would correspond with each fish guild (except forage fish) exceeding US EPA methylmercury criterion $(0.30 \mu \mathrm{g} / \mathrm{g}$ of ww) for the protection of human health. ${ }^{56}$

Using these benchmarks, in concert with the corresponding dragonfly $\mathrm{THg}$ concentrations for different fish guilds, we classified Aeshnid-equivalent $\mathrm{THg}$ concentrations into five indices of progressively increasing severity that incorporated both the magnitude of potential impairment as well as the number of guilds exceeding these individual benchmarks (Figure 5, Table S5). As opposed to simply evaluating individual species, this approach considers the potential risk across multiple guilds, allowing for a broader assessment of the potential ecological and human health exposure risks in freshwater ecosystems. The established impairment benchmarks are still lacking for other taxa, such as amphibians, but their correlations with dragonfly larvae suggest that the development of benchmarks could lead to further refinements of integrated impairment assessments.

Aeshnid-equivalent $\mathrm{THg}$ concentrations below $60 \mathrm{ng} / \mathrm{g} \mathrm{dw}$ were classified as sub-impairment because concentrations in this range were not associated with any benchmark exceedances except the dietary low-risk benchmark for piscivores. In other words, only piscivorous fish would pose a health risk as prey to other piscivores when Aeshnid-equivalent concentrations are below this value. We classified Aeshnid-equivalent concentrations of $60-100 \mathrm{ng} / \mathrm{g} \mathrm{dw}$ as being in the low-hazard integrated impairment index. Within this range, piscivorous fish exceeded the low-risk avian dietary benchmark $(0.10 \mu \mathrm{g} / \mathrm{g}$ ww), and sunfish exceeded the low-risk fish dietary benchmark $(0.05 \mu \mathrm{g} / \mathrm{g} \mathrm{ww})$; however, there were no other exceedances across all guilds. Aeshnid-equivalent $\mathrm{THg}$ concentrations of $100-300 \mathrm{ng} / \mathrm{g} \mathrm{dw}$ were designated as being in the moderate hazard integrated impairment index. In this category, piscivorous fish exceeded both the US EPA $\mathrm{MeHg}$ criterion for the protection of human health and the moderate-risk fish health benchmark. Both piscivorous fish and sunfish exceeded the moderate-risk avian dietary benchmark, and sunfish also exceeded the low-risk fish health benchmark. Additionally, dragonfly larvae, forage fish, and salmonids all exceeded the low-risk fish dietary benchmark. Aeshnid-equivalent $\mathrm{THg}$ concentrations of $300-700 \mathrm{ng} / \mathrm{g}$ of $\mathrm{dw}$ are considered in the high-hazard integrated impairment index because, within that range, piscivorous fish and sunfish exceeded both the moderate-risk fish health and high-risk avian dietary benchmarks. Additionally, sunfish exceeded both the US EPA MeHg criterion and the moderate-risk fish health benchmark. Finally, dragonfly larvae, forage fish, and salmonids all exceeded the low-risk avian dietary benchmark. Aeshnid-equivalent $\mathrm{THg}$ concentrations exceeding $700 \mathrm{ng} / \mathrm{g}$ of $\mathrm{dw}$ represent a potentially severe-hazard risk of $\mathrm{Hg}$ impairment within ecosystems. At those exposure levels, piscivores and sunfish both exceed the high-risk fish dietary and fish health 


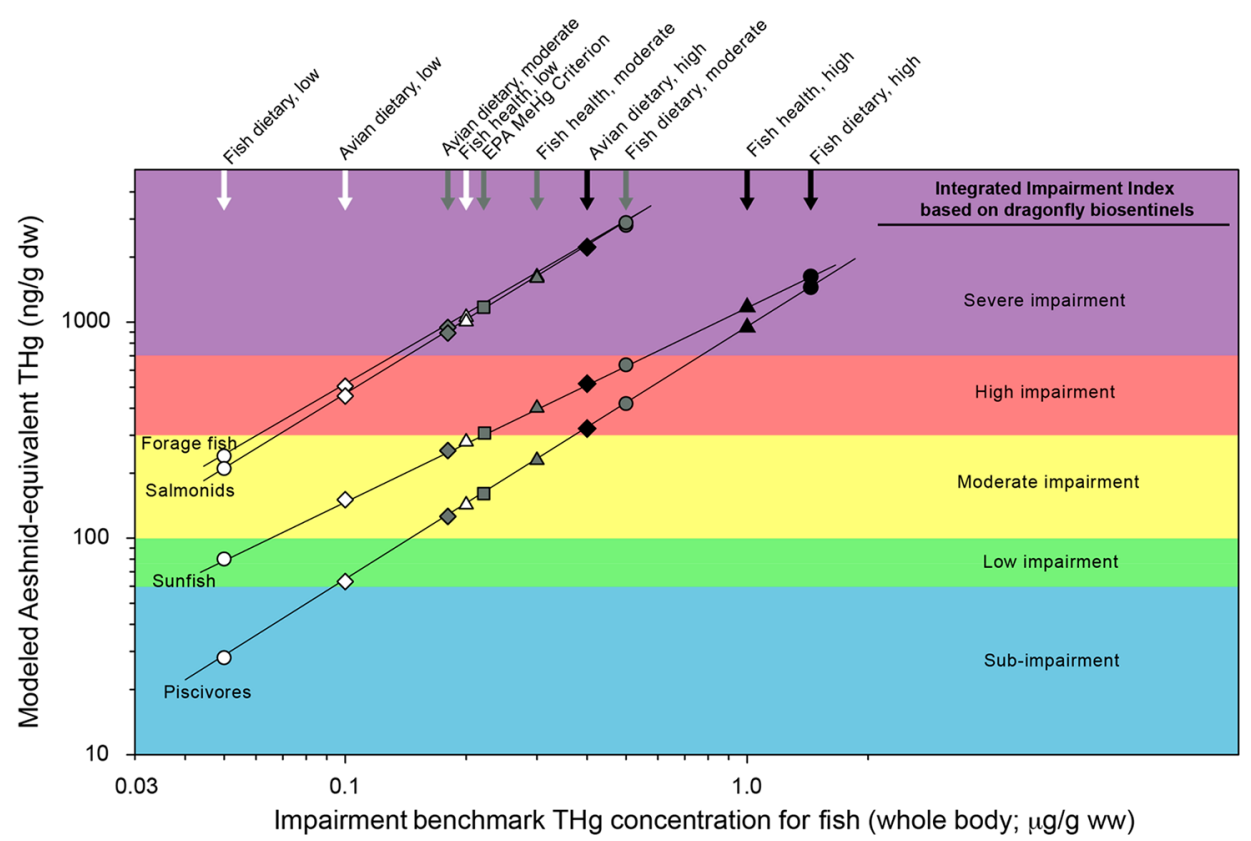

Figure 5. Integrated impairment indices for potential ecosystem risk to mercury, in Aeshnid-equivalent units (ng/g dry weight total mercury $(\mathrm{THg})$ ). Integrated impairment index categories (specified by different colored boxes) represent concentrations corresponding to exceedances of a range of individual published toxicity benchmarks ${ }^{53-55}$ across several fish guilds (piscivores, sunfish, salmonids, and forage fish). Within each of these guilds, the potential impairment was assessed based on (1) fish diet (i.e., risk to other fish as prey), (2) fish tissue (labeled as fish health; i.e., risk to fish themselves based on their tissue concentrations), and (3) avian diet (i.e., risk to fish-eating birds as prey), with three possible levels of severity (low, moderate, and high as white, grey, and black arrows, respectively) for each of these benchmark types. Potential human risk is incorporated through the US EPA methylmercury criterion for the protection of human health, which was converted to a whole-body equivalent. ${ }^{7}$ The integrated impairment indices are defined by the number and severity of benchmarks exceeded as well as the number of guilds exceeding them. The symbols and lines represent the modeled Aeshnid-equivalent $\mathrm{THg}$ concentrations associated with the THg concentrations of each impairment benchmark for each fish guild. Circles represent fish dietary benchmarks, triangles represent fish health benchmarks, diamonds represent avian dietary benchmarks, and squares represent US EPA MeHg criterion. White, gray, and black symbols reflect low, moderate, and high-severity benchmarks, respectively.

benchmarks. Additionally, salmonids exceed the US EPA $\mathrm{MeHg}$ criterion. Salmonids, forage fish, and dragonflies all exceed the moderate-risk fish and avian dietary benchmarks, and salmonids and forage fish also exceed the moderate-risk fish health benchmark.

This integrated approach allows resource managers to simultaneously evaluate the potential exposure and hazard across a range of ecological receptors to more thoroughly assess the threat $\mathrm{Hg}$ may pose to ecosystem function. Overall, $10 \%$ of the 877 site-years had geometric mean Aeshnidequivalent $\mathrm{THg}$ concentrations that were below any of the deleterious effect benchmarks, and $22 \%$ were associated with the low-hazard index. In contrast, more than half of the siteyears $(56 \%)$ were categorized as moderate hazards. Finally, 11 and $1 \%$ of sites had geometric mean Aeshnid-equivalent $\mathrm{THg}$ concentrations that were high enough for them to be classified in the high- or severe-hazard indices, respectively. Geographically, the distribution of risk categories was heterogeneous across the continent (Figure 6). Moreover, within individual park units there were often sites that spanned the entire range of benchmark categories (Figure 6).

The national-scale citizen-science network leveraged herein represents the most expansive assessment of the $\mathrm{MeHg}$ distribution and the potential impairment risk using aquatic macroinvertebrates as biosentinels. We show that dragonfly larvae provide an effective model for understanding important factors of $\mathrm{Hg}$ bioaccumulation and can be used to estimate potential ecosystem impairment. We also demonstrate that widespread $\mathrm{Hg}$ contamination in protected NPS lands poses

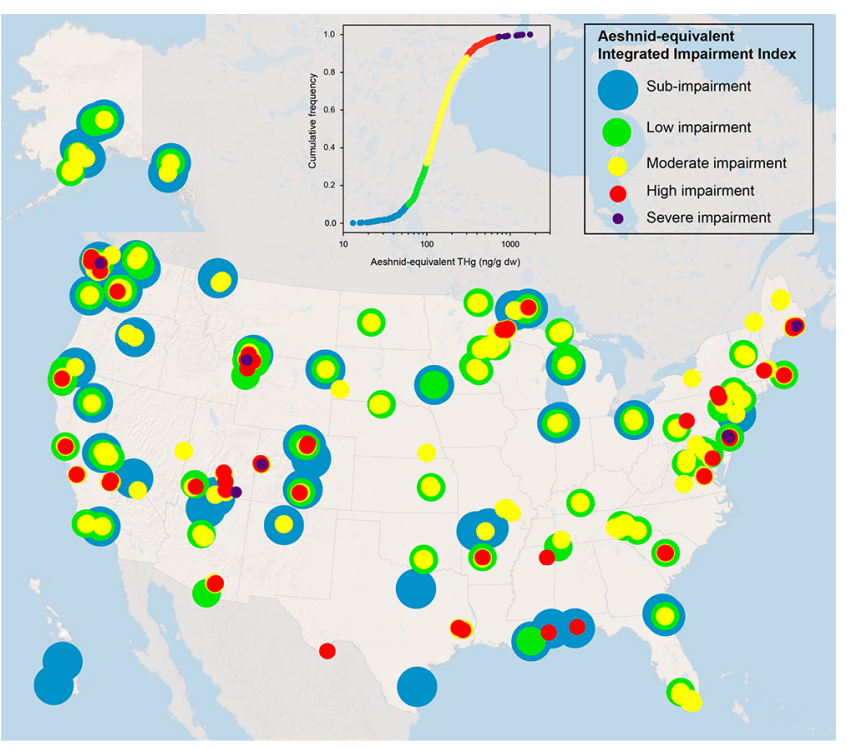

Figure 6. Integrated impairment indices for all 457 sites sampled between 2009 and 2018. Integrated impairment indices are derived from Aeshnid-equivalent geometric mean $\mathrm{THg}$ concentrations for each site-year and their corresponding association with $\mathrm{Hg}$ exposure in fish and other wildlife. The inset for the cumulative frequency distribution illustrates the proportion of sites and years that fall into each of the five categories. Note that the map geography was altered to include Alaska and Hawaii within the map frame. 
risks to trust resources within them. Utilizing a citizen-science framework also provides a cost-effective approach for biological sampling while also engaging the public in experiential learning opportunities. Future applications of dragonfly larvae $\mathrm{Hg}$ monitoring could be particularly insightful for better understanding the landscape, biogeochemical, and climatological drivers of $\mathrm{Hg}$ availability to aquatic food webs; predicting the potential risk to vertebrates; and evaluating the effectiveness of $\mathrm{Hg}$ reductions, both regionally and globally.

\section{ASSOCIATED CONTENT}

\section{sI Supporting Information}

The Supporting Information is available free of charge at https://pubs.acs.org/doi/10.1021/acs.est.0c01255.

Supporting Information includes further details on the methods. Additionally, Figure S1, individual sampling sites for dragonfly larvae in National Park Service units; Figure S2, relationship between dragonfly larvae total mercury $(\mathrm{THg})$ and methylmercury $(\mathrm{MeHg})$ concentrations; Figure S3, least squares mean dragonfly larvae $\mathrm{THg}$ concentrations among level 1 ecoregions; and Figure S4, least squares mean $\mathrm{THg}$ concentrations (ng/g of $\mathrm{dw}$ ) in larvae of five dragonfly families, are included. Also, Table S1, habitat designations and representative sites; Table S2, summary of fish and amphibian species and their respective guild categories; Table S3, unit type and associated codes for various National Park Service units; and Table S5, dietary and tissue concentration benchmarks used to evaluate potential health risks of methylmercury based upon dragonfly larvae $\mathrm{Hg}$ concentrations, are included (PDF)

Table S4, Regression parameters for dragonfly larvae $\mathrm{Hg}$ versus length regressions (XLSX)

\section{AUTHOR INFORMATION}

\section{Corresponding Author}

Collin A. Eagles-Smith - United States Geological Survey, Forest and Rangeland Ecosystem Science Center, Corvallis, Oregon 97330, United States; ○ orcid.org/0000-0003-13295285; Phone: 1+ 541-750-0949; Email: ceagles-smith@ usgs.gov

\section{Authors}

James J. Willacker - United States Geological Survey, Forest and Rangeland Ecosystem Science Center, Corvallis, Oregon 97330, United States; 이이. orcid.org/0000-0002-6286-5224

Sarah J. Nelson - School of Forest Resources, University of Maine, Orono, Maine 04469, United States; Appalachian Mountain Club, Gorham, New Hampshire 03581, United States

Colleen M. Flanagan Pritz - National Park Service, Air Resources Division, National Resource, Stewardship and Science Directorate, Lakewood, Colorado 80228, United States

David P. Krabbenhoft - United States Geological Survey, Upper Midwest Water Science Center, Middleton, Wisconsin 53562, United States; 이이.orid.o000-0003-1964-5020

Celia Y. Chen - Department of Biological Sciences, Dartmouth College, Hanover, New Hampshire 03755, United States

Joshua T. Ackerman - United States Geological Survey, Western Ecological Research Center, Dixon, California 95620, United States; 이이.org/0000-0002-3074-8322
Evan H. Campbell Grant - United States Geological Survey, Patuxent Wildlife Research Center, Turners Falls, Massachussetts 01376, United States

David S. Pilliod - United States Geological Survey, Forest and Rangeland Ecosystem Science Center, Boise, Idaho 83706,

United States; ○ orcid.org/0000-0003-4207-3518

Complete contact information is available at:

https://pubs.acs.org/10.1021/acs.est.0c01255

\section{Notes}

The authors declare no competing financial interest.

\section{ACKNOWLEDGMENTS}

Support for this work was provided by the National Park Service, US Geological Survey (USGS-NPS Water Quality Partnership, Environmental Health Mission Area's Contaminants Biology and Toxics Substances Hydrology Programs, and Ecosystems Mission Area), University of Maine, National Park Foundation. Additional support provided by the Dartmouth Superfund Research Program funded by the National Institute of Environmental Health Sciences (Grant number: P42 ES007373) to Dr. Celia Chen. We thank Colleen Emery, John Pierce, Branden Johnson, Caitlin Rumrill, Tim Glidden, Amanda Klemmer, Megan Hess, Marissa Giroux, Amy Kireta, Kat Ko, Tonnie Cummings, Brandon Kowalski, and other staff at the USGS contaminant ecology research lab for field, lab, and data management assistance. We also value the highly regarded guidance from Tamara Blett, and we appreciate the input and counsel of Roger Haro, David VanderMeulen, Abe Miller-Rushing, and representatives from the United States EPA, United States Fish and Wildlife Service, USGS, and NPS, who sit on the Dragonfly Mercury Project Steering Committee. We thank Helene Bennett for her editorial assistance. The Schoodic Institute at Acadia National Park and Hannah Webber provided educational materials that served as the basis of the experiential opportunities afforded to national parks and citizenry across the country. We are particularly indebted to the numerous dedicated NPS staff across the country for their engagement in this effort and for the thousands of citizen scientists that volunteered their time and energy to collect dragonfly larvae. Any use of trade, product, or firm names is for descriptive purposes only and does not imply an endorsement by the US Government. This is contribution \#753 of the US Geological Survey, Amphibian Research and Monitoring Initiative (ARMI).

\section{REFERENCES}

(1) Driscoll, C. T.; Mason, R. P.; Chan, H. M.; Jacob, D. J.; Pirrone, N. Mercury as a global pollutant: sources, pathways, and effects. Environ. Sci. Technol. 2013, 47 (10), 4967-83.

(2) Chen, C. Y.; Driscoll, C. T.; Eagles-Smith, C. A.; Eckley, C. S.; Gay, D. A.; Hsu-Kim, H.; Keane, S. E.; Kirk, J. L.; Mason, R. P.; Obrist, D.; Selin, H.; Selin, N. E.; Thompson, M. R. A Critical Time for Mercury Science to Inform Global Policy. Environ. Sci. Technol. 2018, 52 (17), 9556-9561.

(3) Drenner, R. W.; Chumchal, M. M.; Jones, C. M.; Lehmann, C. M.; Gay, D. A.; Donato, D. I. Effects of mercury deposition and coniferous forests on the mercury contamination of fish in the South Central United States. Environ. Sci. Technol. 2013, 47 (3), 1274-9.

(4) Eagles-Smith, C. A.; Wiener, J. G.; Eckley, C. S.; Willacker, J. J.; Evers, D. C.; Marvin-DiPasquale, M.; Obrist, D.; Fleck, J. A.; Aiken, G. R.; Lepak, J. M.; Jackson, A. K.; Webster, J. P.; Stewart, A. R.; Davis, J. A.; Alpers, C. N.; Ackerman, J. T. Mercury in western North America: A synthesis of environmental contamination, fluxes, 
bioaccumulation, and risk to fish and wildlife. Sci. Total Environ. 2016, 568, 1213-1226.

(5) Obrist, D.; Kirk, J. L.; Zhang, L.; Sunderland, E. M.; Jiskra, M.; Selin, N. E. A review of global environmental mercury processes in response to human and natural perturbations: changes of emissions, climate and land use. Ambio 2018, 47, 116-140.

(6) Selin, H.; Keane, S.; Selin, N. E.; Wang, S.; Bally, D.; Davis, K. Linking Science and Policy to Support the Implementation of the Minamata Convention. Ambio 2018, 47, 198-215.

(7) Eagles-Smith, C. A.; Ackerman, J. T.; Willacker, J. J.; Tate, M. T.; Lutz, M. A.; Fleck, J. A.; Stewart, A. R.; Wiener, J. G.; Evers, D. C.; Lepak, J. M.; Davis, J. A.; Pritz, C. F. Spatial and temporal patterns of mercury concentrations in freshwater fish across the Western United States and Canada. Sci. Total Environ. 2016, 568, 1171-1184.

(8) Chasar, L. C.; Scudder, B. C.; Stewart, A. R.; Bell, A. H.; Aiken, G. R. Mercury Cycling in Stream Ecosystems. 3. Trophic Dynamics and Methylmercury Bioaccumulation. Environ. Sci. Technol. 2009, 43 (8), 2733-2739.

(9) Ackerman, J. T.; Fleck, J. A.; Eagles-Smith, C. A.; MarvinDiPasquale, M.; Windham-Myers, L.; Herzog, M. P.; McQuillen, H. L. Wetland Management Strategy to Reduce Mercury in Water and Bioaccumulation in Fish. Environ. Toxicol. Chem. 2019, 38 (10), 2178-2196.

(10) Beeby, A. What do sentinels stand for? Environ. Pollut. 2001, 112 (2), 285-298.

(11) Wiener, J. G.; Bodaly, R. A.; Brown, S. S.; Lucotte, M.; Newman, M. C.; Porcella, D. B.; Reash, R. J.; Swain, E. B., Monitoring and evaluating trends in methylmercury accumulation in aquatic biota. In Ecosystem Responses to Mercury Contamination: Indicators of Change; Harris, R. C.; Krabbenhoft, D. P.; Mason, R.; Murray, M. W.; Reash, R. J.; Saltman, T., Eds.; CRC Press/Taylor and Francis: Boca Raton, FL, 2007; pp 87-122.

(12) Lavoie, R. A.; Baird, C. J.; King, L. E.; Kyser, T. K.; Friesen, V. L.; Campbell, L. M. Contamination of Mercury during the Wintering Period Influences Concentrations at Breeding Sites in Two Migratory Piscivorous Birds. Environ. Sci. Technol. 2014, 48 (23), 13694-13702.

(13) Schilling, E. G.; Loftin, C. S.; Degoosh, K. E.; Huryn, A. D.; Webster, K. E. Predicting the locations of naturally fishless lakes. Freshwater Biol. 2008, 53 (5), 1021-1035.

(14) Andersen, J. L.; Depledge, M. H. A survey of total mercury and methylmercury in edible fish and invertebrates from Azorean waters. Mar. Environ. Res. 1997, 44 (3), 331-350.

(15) Corbet, P. S. Dragonflies: behavior and ecology of Odonata; Cornell University Press: Ithaca, NY, 1999; p 829.

(16) Buckland-Nicks, A.; Hillier, K. N.; Avery, T. S.; O’Driscoll, N. J. MERCURY BIOACCUMULATION IN DRAGONFLIES (ODONATA: ANISOPTERA): EXAMINATION OF LIFE STAGES AND BODY REGIONS. Environ. Toxicol. Chem. 2014, 33 (9), 2047-2054.

(17) Haro, R. J.; Bailey, S. W.; Northwick, R. M.; Rolf-Hus, K. R.; Sandheinrich, M. B.; Wiener, J. G. Burrowing Dragonfly Larvae as Biosentinels of Methylmercury in Freshwater Food Webs. Environ. Sci. Technol. 2013, 47 (15), 8148-8156.

(18) Nelson, S. J.; Chen, C. Y.; Kahl, J. S., Dragonfly larvae as biosentinels of $\mathrm{Hg}$ bioaccumulation in Northeastern and Adirondack lakes: relationships to abiotic factors. Ecotoxicology 2019.

(19) Jeremiason, J. D.; Reiser, T. K.; Weitz, R. A.; Berndt, M. E.; Aiken, G. R. Aeshnid dragonfly larvae as bioindicators of methylmercury contamination in aquatic systems impacted by elevated sulfate loading. Ecotoxicology 2016, 25 (3), 456-468.

(20) Williams, E. B.; Chumchal, M. M.; Drenner, R. W.; Kennedy, J. H. Seasonality of Odonate-Mediated Methylmercury Flux from Permanent and Semipermanent Ponds and Potential Risk to RedWinged Blackbirds (Agelaius phoeniceus). Environ. Toxicol. Chem. 2017, 36 (10), 2833-2837.

(21) Pfleeger, A. Z.; Eagles-Smith, C. A.; Kowalski, B. M.; Herring, G.; Willacker, J. J.; Jackson, A. K.; Pierce, J. R. From tails to toes: developing nonlethal tissue indicators of mercury exposure in five amphibian species. Ecotoxicology 2016, 25 (3), 574-583.
(22) US EPA. Test methods for evaluating solid waste, physical/ chemical methods. Method 7473; US Environmental Protection Agency: Springfield, VA, 2000.

(23) US EPA. Methyl Mercury in Water by Distillation, Aqueous Ethylation, Purge and Trap, and CVAFS. Method 1630; US Environmental Protection Agency: Washington, D.C., 2001.

(24) Omernik, J. Ecoregions of the conterminous United States. Annals of the Association of American Geographers 1987, 77 (1), 118225

(25) Ackerman, J. T.; Takekawa, J. Y.; Eagles-Smith, C. A.; Iverson, S. A. Mercury contamination and effects on survival of American avocet and black-necked stilt chicks in San Francisco Bay. Ecotoxicology 2008, 17 (2), 103-116.

(26) Ackerman, J. T.; Hartman, C. A.; Herzog, M. P. Mercury contamination in resident and migrant songbirds and potential effects on body condition. Environ. Pollut. 2019, 246, 797-810.

(27) Depew, D. C.; Burgess, N. M.; Campbell, L. M. Modelling mercury concentrations in prey fish: derivation of a national-scale common indicator of dietary mercury exposure for piscivorous fish and wildlife. Environ. Pollut. 2013, 176, 234-43.

(28) Eagles-Smith, C. A.; Herring, G.; Johnson, B.; Graw, R. Conifer density within lake catchments predicts fish mercury concentrations in remote subalpine lakes. Environ. Pollut. 2016, 212, 279-289.

(29) Eagles-Smith, C. A.; Willacker, J. J.; Flanagan Pritz, C. M.. Mercury in Fishes from 21 National Parks in the Western United States-Inter-and Intra-Park Variation in Concentrations and Ecological Risk; Open-File Report 2014-1051; US Geological Survey: Corvallis, Oregon, 2014; p 54. DOI: 10.3133/ofr20141051

(30) Schwindt, A. R.; Fournie, J. W.; Landers, D. H.; Schreck, C. B.; Kent, M. L. Mercury Concentrations in Salmonids from Western U.S. National Parks and Relationships with Age and Macrophage Aggregates. Environ. Sci. Technol. 2008, 42 (4), 1365-1370.

(31) Eagles-Smith, C. A.; Ackerman, J. T. Mercury bioaccumulation in estuarine wetland fishes: evaluating habitats and risk to coastal wildlife. Environ. Pollut. 2014, 193, 147-155.

(32) Kamman, N. C.; Burgess, N. M.; Driscoll, C. T.; Simonin, H. A.; Goodale, M. W.; Linehan, J. C.; Estabrook, R.; Hutcheson, M. S.; Major, A.; Scheuhammer, A.; Scruton, D. A. Mercury in Freshwater Fish of Northeast North America - A Geographic Perspective Based on Fish Tissue Monitoring Databases. Ecotoxicology 2005, 14, 163180.

(33) Hall, B. D.; Aiken, G. R.; Krabbenhoft, D. P.; MarvinDiPasquale, M.; Swarzenski, C. M. Wetlands as principal zones of methylmercury production in southern Louisiana and the Gulf of Mexico region. Environ. Pollut. 2008, 154 (1), 124-134.

(34) Bradley, P. M.; Journey, C. A.; Brigham, M. E.; Burns, D. A.; Button, D. T.; Riva-Murray, K. Intra- and inter-basin mercury comparisons: Importance of basin scale and time-weighted methylmercury estimates. Environ. Pollut. 2013, 172, 42-52.

(35) Chan, C.; Heinbokel, J. F.; Myers, J. A.; Jacobs, R. R. A dynamic model using monitoring data and watershed characteristics to project fish tissue mercury concentrations in stream systems. Integr. Environ. Assess. Manage. 2012, 8 (4), 709-722.

(36) Braaten, H. F. V.; de Wit, H. A.; Larssen, T.; Poste, A. E. Mercury in fish from Norwegian lakes: The complex influence of aqueous organic carbon. Sci. Total Environ. 2018, 627, 341-348.

(37) Broadley, H. J.; Cottingham, K. L.; Baer, N. A.; Weathers, K. C.; Ewing, H. A.; Chaves-Ulloa, R.; Chickering, J.; Wilson, A. M.; Shrestha, J.; Chen, C. Y. Factors affecting $\mathrm{MeHg}$ bioaccumulation in stream biota: the role of dissolved organic carbon and diet. Ecotoxicology 2019, 28 (8), 949-963.

(38) Chetelat, J.; Richardson, M. C.; MacMillan, G. A.; Amyot, M.; Poulain, A. J. Ratio of methylmercury to dissolved organic carbon in water explains methylmercury bioaccumulation across a latitudinal gradient from north-temperate to arctic lakes. Environ. Sci. Technol. 2018, 52 (1), 79-88.

(39) Taylor, V. F.; Buckman, K. L.; Seelen, E. A.; Mazrui, N. M.; Balcom, P. H.; Mason, R. P.; Chen, C. Y. Organic carbon content drives methylmercury levels in the water column and in estuarine food 
webs across latitudes in the Northeast United States. Environ. Pollut. 2019, 246, 639-649.

(40) Omernik, J. Perspectives on the nature and definition of ecological regions. Environ. Manage. 2004, 34 (S1), S27-S38.

(41) Eagles-Smith, C. A.; Silbergeld, E. K.; Basu, N.; Bustamante, P.; Diaz-Barriga, F.; Hopkins, W. A.; Kidd, K. A.; Nyland, J. F. Modulators of mercury risk to wildlife and humans in the context of rapid global change. Ambio 2018, 47 (2), 170-197.

(42) French, K. J.; Anderson, M. R.; Scruton, D. A.; Ledrew, L. J. Fish mercury levels in relation to characteristics of hydroelectric reservoirs in Newfoundland. Biogeochemistry 1998, 40 (2-3), 217233.

(43) Gerrard, P. M.; St. Louis, V. L. The effects of experimental reservoir creation on the bioaccumulation of methylmercury and reproductive success of tree swallows (Tachycineta bicolor). Environ. Sci. Technol. 2001, 35 (7), 1329-1338.

(44) Willacker, J. J.; Eagles-Smith, C. A.; Lutz, M. A.; Tate, M. T.; Lepak, J. M.; Ackerman, J. T. Reservoirs and water management influence fish mercury concentrations in the western United States and Canada. Sci. Total Environ. 2016, 568, 739-748.

(45) Ackerman, J. T.; Eagles-Smith, C. A. Agricultural wetlands as potential hotspots for mercury bioaccumulation: experimental evidence using caged fish. Environ. Sci. Technol. 2010, 44 (4), 1451-7.

(46) Eagles-Smith, C. A.; Ackerman, J. T.; Fleck, J.; WindhamMyers, L.; McQuillen, H. L.; Heim, W. Wetland management and rice farming strategies to decrease methylmercury bioaccumulation and loads from the Cosumnes River Preserve, California; Open-File Report 20141172; US Geological Survey: Corvallis, OR, 2014; p 42.

(47) Chetelat, J.; Ackerman, J. T.; Eagles-Smith, C. A.; Hebert, C. Methylmercury exposure in wildlife: A review of the ecological and physiological processes affeting contaminant concentrations and their interpretation. Sci. Total Environ. 2020, 711 (2020), 135117.

(48) Scudder Eikenberry, B. C.; Riva-Murray, K.; Knightes, C. D.; Journey, C. A.; Chasar, L. C.; Brigham, M. E.; Bradley, P. M. Optimizing fish sampling for fish-mercury bioaccumulation factors. Chemosphere 2015, 135, 467-73.

(49) Evers, D. C.; Williams, K. A.; Meyer, M. W.; Scheuhammer, A. M.; Schoch, N.; Gilbert, A. T.; Siegel, L.; Taylor, R. J.; Poppenga, R.; Perkins, C. R. Spatial gradients of methylmercury for breeding common loons in the Laurentian Great Lakes region. Ecotoxicology 2011, 20 (7), 1609-25.

(50) Ackerman, J. T.; Hartman, C. A.; Eagles-Smith, C. A.; Herzog, M. P.; Davis, J.; Ichikawa, G.; Bonnema, A. Estimating mercury exposure of piscivorous birds and sport fish using prey fish monitoring. Environ. Sci. Technol. 2015, 49 (22), 13596-13604.

(51) Jackson, A.; Evers, D. C.; Eagles-Smith, C. A.; Ackerman, J. T.; Willacker, J. J.; Elliott, J. E.; Lepak, J. M.; Vander Pol, S. S.; Bryan, C. E. Mercury risk to avian piscivores acrosswestern United States and Canada. Sci. Total Environ. 2016, 568, 685-696.

(52) Ackerman, J. T.; Eagles-Smith, C. A.; Herzog, M. P.; Hartman, C. A.; Peterson, S. H.; Evers, D. C.; Jackson, A. K.; Elliott, J. E.; Vander Pol, S. S.; Bryan, C. E. Avian mercury exposure and toxicological risk across western North America: A synthesis. Sci. Total Environ. 2016, 568, 749-769.

(53) Depew, D. C.; Basu, N.; Burgess, N. M.; Campbell, L. M.; Devlin, E. W.; Drevnick, P. E.; Hammerschmidt, C. R.; Murphy, C. A.; Sandheinrich, M. B.; Wiener, J. G. Toxicity of dietary methylmercury to fish: Derivation of ecologically meaningful threshold concentrations. Environ. Toxicol. Chem. 2012, 31 (7), 1536-1547.

(54) Depew, D. C.; Basu, N.; Burgess, N. M.; Campbell, L. M.; Evers, D. C.; Grasman, K. A.; Scheuhammer, A. M. Derivation of screening benchmarks for dietary methylmercury exposure for the common loon (Gavia immer): rationale for use in ecological risk assessment. Environ. Toxicol. Chem. 2012, 31 (10), 2399-407.

(55) Sandheinrich, M. B.; Bhavsar, S. P.; Bodaly, R. A.; Drevnick, P. E.; Paul, E. A. Ecological risk of methylmercury to piscivorous fish of the Great Lakes region. Ecotoxicology 2011, 20 (7), 1577-87.
(56) Borum, D.; Manibusan, M.; Schoeny, R.; Winchester, E. Water Quality Criterion for the Protections of Human Health: Methylmercury; EPA-823-R-01-001; US Environmental Protection Agency: Washington, D.C., 2001. 